\title{
Morphological variation of Keratella cochlearis in the presence of cyclopoid copepods in Meimoa Reservoir
}

\author{
Célia F. Baião, Maria-José Caramujo \& Maria-José Boavida ${ }^{1}$ \\ Centro de Biología Ambiental. Dept. de Zoologia e Antropologia. Faculdade de Ciências da Universidade de \\ Lisboa. Campo Grande, C2. 1700 Lisboa. Portugal .1 To whom correspondence should be sent.
}

\begin{abstract}
Species succession and succession of different morphs of the same species throughout the year are frequently reported. Environmental factors have been considered uneffective to justify such variations while the role of biotic relationships has received increasing attention. During this study the importance of biotic factors on body and spine lengths variation of Keratella cochlearis (Rotifera) during 1995 in Meimoa Reservoir was investigated. The predation impact on K. cochlearis morphology was evidenced as a general increase of body and spine lengths in the presence of potential cyclopoid predators. The importance of predator species composition and abundance on morphological variation of K. cochlearis was emphasised by direct correlation of both spine and body lengths to Acanthocyclops robustus density and not to the whole cyclopoid population.
\end{abstract}

Keywords: Spine elongation, Rotifera, Acanthocyclops robustus.

\section{RESUMEN}

La sucesión de especies y la sucesión de diferentes formas de la misma especie a lo largo del año han sido descritas frecuentemente. Los factores ambientales han sido considerados insuficientes para justificar tales variaciones, mientras que el papel de las relaciones bióticas ha recibido una atención creciente. En este estudio se ha investigado durante 1995 la importancia de los factores bióticos en el tamaño del cuerpo y de las espinas de Keratella cochlearis (Rotifera) en el embalse de Meimoa. El impacto de la depredación sobre la morfología de K. cochlearis ha sido claro en el incremento general del tamaño del cuerpo y de las espinas en presencia de los ciclópidos potenciales depredadores. La importancia de la abundancia y composición de las especies depredadoras en las variaciones morfológicas de $\mathrm{K}$. cochlearis ha sido puesta de relieve mediante la existencia de correlaciones positivas entre los tamaños del cuerpo y de las espinas con la densidad de Acanthocyclops robustus y no con la de todo el conjunto de la población de ciclópidos.

Palabras clave: alargamiento de las espinas, Rotifera, Acanthocyclops robustus.

\section{INTRODUCTION}

Copepods interact with rotifers in various ways. Since all copepod species have herbivorous development stages they interact with rotifers by exploitative competition for phytoplankton or bacteria (Neill, 1984; Soto \& Hurlbert, 1990). Predation by both calanoids and cyclopoids has been reported (Williamson \& Butler, 1986; Roche, 1990a, 1990b) and direct mechanical dama- ge may be caused by active swimming (Burns \& Gilbert, 1986). To allow coexistence with predators, rotifers develop a panoply of defensive mechanisms comprehending morphological defences, presence of mucus sheath and enhancement of escape responses, among others (Stemberger \& Gilbert, 1987).

Investment in spines is the most common form of morphological structure and responses to predator presence may involve development of poste- 
rior spine and/or elongation of spines. Effectiveness depends both on the length of spines and on the stiffness and thickness of the skeletal material in the body wall (Stemberger \& Gilbert, 1987).

The release of a water soluble factor by Tropocyclops prasinus and Mesocyclops edax has been reported to induce the development of one spine in an unspined Keratella cochlearis clone (Stemberger \& Gilbert, 1984). The concentration of this factor may be of importance since Marinone \& Zagarese (1991) have shown that the degree of spine enlargement in Keratella tropica is directly related to Acanthocyclops robustus density. The advantage of posterior spine elongation seems to be due to a decrease in the probability of ingestion after encounter rather than reduced encounter probability with the predator. In Meimoa Reservoir, preliminary sampling revealed the existence of periods in which Keratella cochlearis exhibited a developed spine. In order to relate this spine elongation to potential invertebrate predators, especially copepods, a sampling program was designed. The effect of total copepod community was separated from the effect of one species or assemblages of species.

Meimoa reservoir is located in the Tagus River watershed. It is a recent reservoir first filled in 1986 and undergoing a rapid process of eutrophication (unpubl. data). In the site studied, near the dam, depth varied from 20 to 30 meters in the year of 1995 .

\section{METHODS}

Zooplankton samples were taken with a van Dorn bottle (2 L capacity) at 5 meters intervals from 1 $\mathrm{m}$ depth until $20 \mathrm{~m}$ depth for density calculations. A vertical tow with a Wisconsin type net of 30 $\mu \mathrm{m}$ mesh size was taken to collect animals for size measurements. Animals were anaesthetised in carbonated water and preserved in sugar saturated formalin $(4 \% \mathrm{v} / \mathrm{v})$. Measurements were made under a microscope (error: $\pm 1.25 \mu \mathrm{m}$ ) from the anterior to the posterior edge of body, without spine. Spine was measured separately. Fecundity was calculated as the number of eggs per total of females. Body and spine length were fitted to a line $(y=a+b x)$ using cyclopoid densities as independent variable.

ANOVA analysis was applied to body length using date as factor and post-hoc tests were applied to determine which dates were significantly different from the others. To assess whether there was a difference in spine length between sampling dates, ANCOVA was applied using body length as covariate.

Spearman correlation coefficient was calculated to estimate the relation of spine and body length to density of predator copepod stages (i.e. copepodite stage four (CIV) to adults (CVI)).

\section{RESULTS}

Daphnia was sporadically present in the reservoir during the sampling period but population densities were always below 1 ind.L $L^{-1}$. Asplanchna was present only on one sampling date (25 August) with density equal to 0.25 ind. $\mathrm{L}^{-1}$.

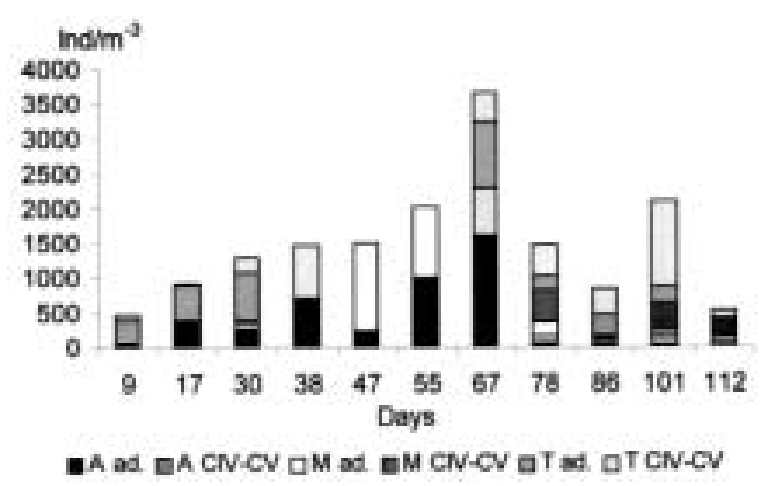

Figure 1. Densities of main copepod species in Meimoa Reservoir from June 9 to September 20 of 1995. A - Acanthocyclops robustus; M - Macrocyclops albidus ; T - Tropocyclops prasinus; ad.- adults; CIV-CV - copepodite stages four and five. Abundancia de las principales especies de copépodos en el embalse de Meimoa; A Acanthocyclops robustus ; $M$ - Macrocyclops albidus; $T$ Tropocyclops prasinus; ad.- adultos; $C I V$ - CV - estadios copepodito cuarto y quinto. 


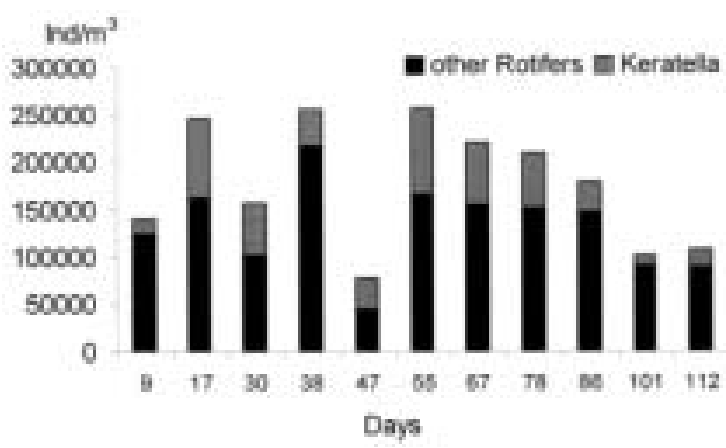

Figure 2. Densities of Keratella cochlearis and other rotifers in Meimoa Reservoir during the sampling period. Abundancia de Keratella cochlearis y otros rotíferos en el embalse de Meimoa durante el periodo de muestreo.

\section{Potential predators}

The assemblage of copepodid IV to adults belonging to main copepod species in the reservoir, increased from the beginning of the sampling period until day 67 (6 August) (Fig. 1).

Acanthocyclops robustus was present after day 17 (17/June) and was the main contributor to potential predators present from day 38 to 67
(8/July to 6/August). Afterwards its density decreased abruptly and remained low (Fig. 1).

Macrocyclops albidus was present from late August to the end of September always in low numbers.

Tropocyclops robustus was present mainly as adults in the beginning of the sampling period. During July late copepodite stages and adults of this species disappeared from the reservoir and only after day 67 (6/August) adults and copepodite stages were present. After a small decrease in the following sampling dates this species was present until 9 of September.

\section{Keratella cochlearis}

$K$. cochlearis was always present during the sampling period. Population numbers were high after day 17 (17/June) and decreased abruptly after day 87 (25/August) (Fig. 2). Maximum was recorded on day 55 (5/July).

Fecundity decreased in June after a maximum in the first sampling date. Afterwards, values increased toward the end of July. During August fecundity decreased and minimum was recorded in the last week of August (Fig. 3).

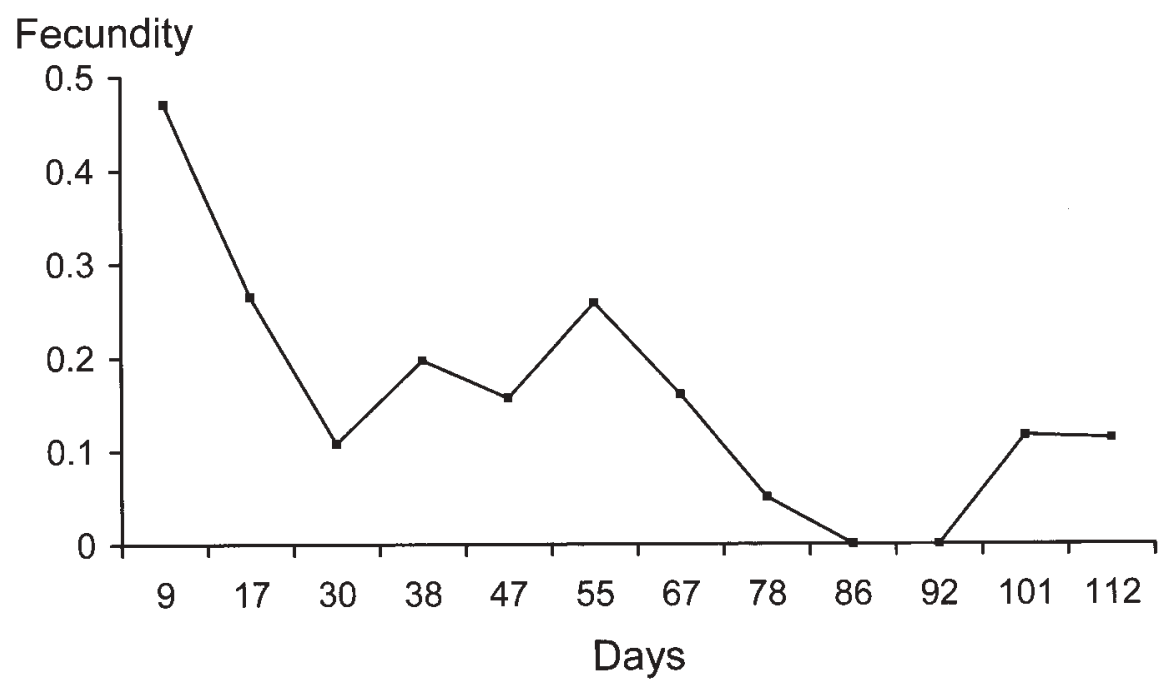

Figure 3. Fecundity of Keratella cochlearis during the sampling period calculated as the number of eggs per female. Fecundidad de Keratella cochlearis calculada como el número de huevos por hembra durante el período de muestreo. 


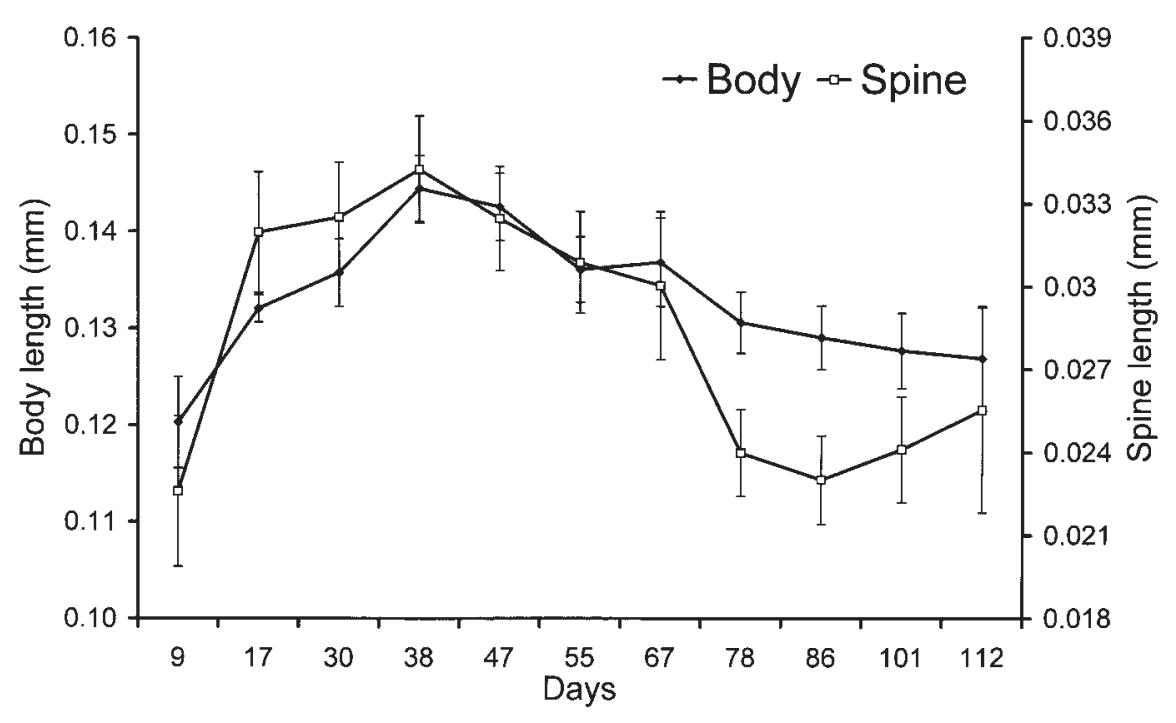

Figure 4. Body and spine lengths during the sampling period (error bars indicate $95 \%$ confidence intervals). Tamaños del cuerpo y de las espinas durante el periodo de muestreo (las barras indican los intervalos de confianza al 95\%).

Body length increased until day 38 (8/July) and then decreased smoothly until the end of the sampling period. Spine length followed the trend in body length although a sharp decrease was recorded after day 67 (6/August) (Fig. 4).

Body length was significantly different among dates (ANOVA, $\mathrm{F}_{9,407}=19.46, \mathrm{p}<0.001$ ). Post-hoc tests $(p<0.01)$ revealed that on day 9 (9/June) body length was significantly smaller than on all other dates and body length on days 38 and 47 were significantly larger than on all other dates.

Spine length varied significantly among sampling dates (ANCOVA, $\mathrm{F}_{9.407}=33.77, \mathrm{p}<0.001$ ) and post-hoc tests $(\mathrm{p}<0.01)$ revealed that spine length on dates 78, 86, 101 (17/August, 25/August and 9/September, respectively) was significantly smaller than on all other dates. Spine length on dates 17, 30, 38 (17/June, 30/June and $8 /$ July, respectively) was significantly larger than on all other dates.

Body and spine length were not correlated to total copepod densities nor to $M$. albidus nor to $T$. prasinus densities (Fig. 5). Body and spine length were significantly correlated to A. robustus den- sities $(r=0.88, p<0.001 ; r=0.69, p<0.05$, respectively) (Fig. 6).

\section{DISCUSSION}

Due to their scarcity we can dismiss Daphnia as a possible competitor to $K$. cochlearis. During the summer, two periods could be distinguished relatively to $K$. cochlearis spine length. A period when $K$. cochlearis spine length is large (17/June to 6/August) and a second period when $K$. cochlearis exhibited a smaller spine (17/August to 20/September and the first sampling date, 9/June). Conde-Porcuna et al. (1993) reported two similar periods, relating the period of longer spine length to high predation pressure by Tropocyclops, Mesocyclops and Asplanchna. Since Asplanchna was present only on one sampling date, their predation impact on $K$. cochlearis should be considered as negligible.

However, during our study we didn't find evidence that spine length was a direct function of the density of total potential predators since spine 


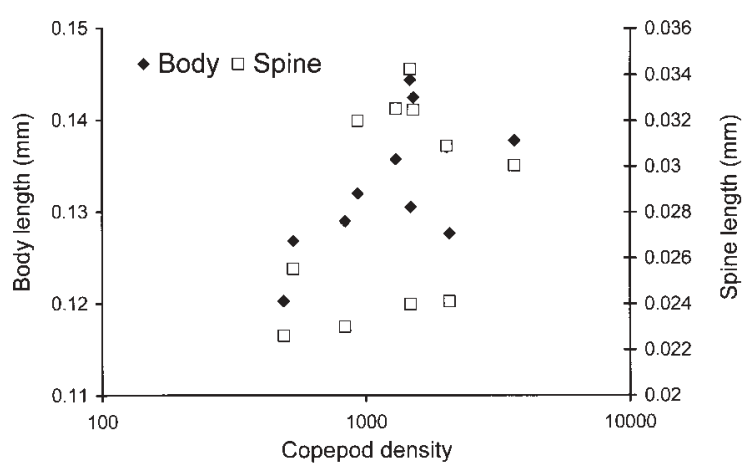

Figure 5. Relationship between spine and body lengths of Keratella cochlearis and copepod densities (as individuals $/ \mathrm{m}^{3}$ ). Note the logarithmic scale of copepod densities. Relaciones entre los tamños de las espinas y del cuerpo de Keratella cochlearis y la densidad de copépodos (como individuos $/ \mathrm{m}^{3}$ ). Observese la escala logaritmica de las densidades de copépodos.

length was not correlated to predator density. Instead of a response to total predator density, apparently spine elongation was a response only to the presence of $A$. robustus. T. prasinus has been referred in literature as an omnivorous species unable to cause significant damage to other zooplankton (Peacko \& Smyli, 1983) but further studies have demonstrated that it can prey on rotifers in particular on $K$. cochlearis and it is able to induce the development of spines (Stemberger \& Gilbert, 1984). Our data do not show such relation between $T$. prasinus density and $K$. cochlearis spine elongation. This may be ascribed to the small population of the copepod present in the reservoir.

We could also speculate whether (i) the presence of enlarged spine $K$. cochlearis during the period of large population of A. robustus could be just a result of the selective predation upon rotifers with no or small spine instead or (ii) a reflection of a general tendency of $K$. cochlearis population to increase their spine in the presence of predators. However, when A. robustus decreased to small population numbers (from day 78 onwards), only small spined individuals were observed rather than an even distribution of individuals among the several possible spine size classes and spine/body ratio decreased abruptly. It is thus tempting to interpret the enlargement of spine during the period of high predator density to a direct response to predator pressure. Furthermore, Marinone \& Zagarese (1991) determined both in field and in laboratory experiments that spine length was a continuous variable directly related to the concentration of A. robustus; this result supports our interpretation.

Enlargement of spine and body can't just be a reflex of better feeding conditions during the first
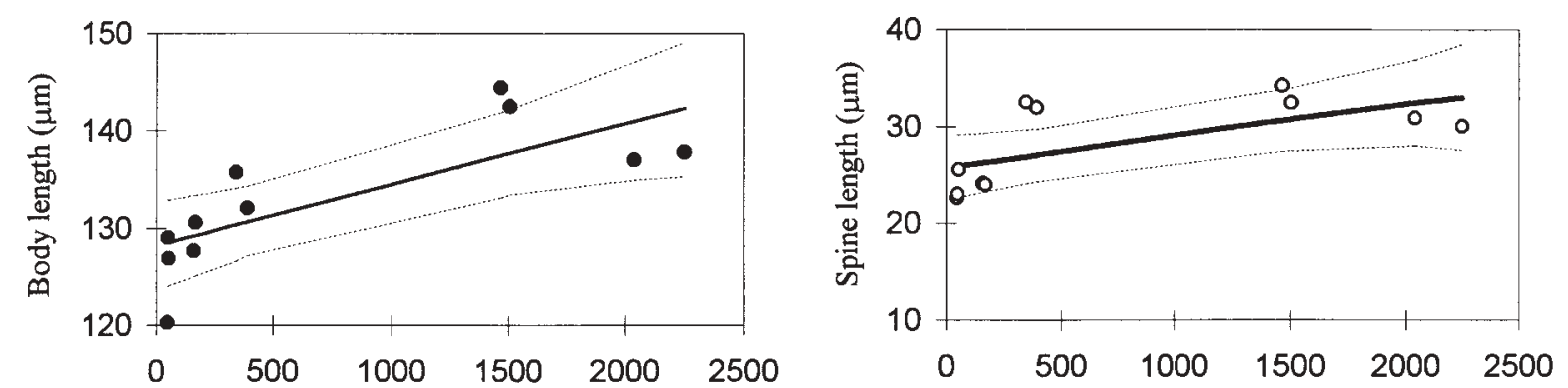

Density of Acanthocyclops robustus (individuals $\mathrm{m}^{-3}$ )

$$
\text { - Body } \quad \circ \text { Spine Regression ……..... Confidence Limits }
$$

Figure 6. Relationship between body and spine length and density of Acanthocyclops robustus. Body: $\mathrm{r}^{2}=0.586$; slope significantly different from zero ( $\mathrm{p}<0.01)$; Spine: $\mathrm{r}^{2}=0.421$; slope significantly different from zero $(\mathrm{p}<0.05)$. Relación entre los tamaños de las espinas y del cuerpo con la densidad de Acanthocyclops robustus. Con el cuerpo $r^{2}=0.586$; pendiente significativamente diferente de cero ( $\left.p<0.01\right)$; con las espinas; $r^{2}=0.421$; pendiente significativamente diferente de cero $(p<0.05)$. 
half of the sampling period since fecundity was decreasing. A decrease in spine length was only observed when $A$. robustus reached extremely low numbers. By that time K. cochlearis population numbers decreased sharply and almost no egg bearing females were observed which can be ascribed to severe feeding conditions. Therefore spine remained short since on one hand predators were no longer a threat, and on the other hand food was scarce.

Our study indicates that predator species and abundance may play a crucial role in spine enlargement of $K$. cochlearis. Nevertheless the role of food availability and the energetic costs of spine enlargement deserve further investigation.

\section{ACKNOWLEDGEMENTS}

This study was partially supported by a doctoral grant (BD-3324/94) awarded to C. Baião by J.N.I.C.T Portugal.

\section{REFERENCES}

BURNS, C. W. \& J.J. GILBERT. 1986. Effects of daphnid size and density on interference between Daphnia and Keratella cochlearis. Limnol. \& Oceanogr., 31: 848-858.

CONDE-PORCUNA J. M., R. MORALES-BAQUERO \& L. CRUZ-PIZARRO. 1993. Effectiveness of the caudal spine as a defense mechanism in Keratella cochlearis. Hydrobiologia, 255/256: 283287.

MARINONE, M. C. \& H.E. ZAGARESE. 1991. A field and laboratory study on factors affecting polymorphism in the rotifer Keratella tropica. Oecologia, 86: 372-377.

NEILL, W. E. 1984. Regulation of rotifer densities by crustacean zooplankton in an oligotrophic mountain lake in British Columbia. Oecologia (Berlin), 61: 175-181.

PEACOCK, A. \& W. J.P. SMYLI. 1983. Experimental studies on the factors limiting Tropocyclops prasinus (Fisher) 1860 in an oligotrophic lake. Can. J. of Zoology, 61: 250-265.
ROCHE, K. 1990a. Some aspects of vulnerability to cyclopoid predation of zooplankton prey individuals. Hydrobiologia, 198: 153-162.

ROCHE, K., 1990b. Prey features affecting ingestion rates by Acanthocyclops robustus (Copepoda: Cyclopoida) on zooplankton. Oecologia, 83: 76-82.

SOTO, D. \& S.H. HURLBERT. 1991. Long term experiments on Calanoid-Cyclopoid interactions. Ecological Monographs, 61: 245-265.

STEMBERGER R. S. \& J.J. GILBERT. 1984. Spine development in the rotifer Keratella cochlearis: induction by cyclopoid copepods and Asplanchna. Freshwater Biology, 14: 639-647.

STEMBERGER R. S. \& J.J. GILBERT. 1987. Defences of planktonic rotifers against predators. In: Predation: Direct and Indirect Impact on Aquatic Communities W.C. Kerfoot \& Sih (eds.): 227-239. Un. Press. New England.

WILLIAMSON, C. E. \& N.M. BUTLER. 1986. Predation on rotifers by a suspension-feeding calanoid copepod Diaptomus pallidus. Limnol. \& Oceanog., 31: 393-402. 